\title{
RISET EVALUASI PASAR KAGET DI KOTA BATAM
}

\author{
${ }^{1}$ Tiurniari Purba \\ ${ }^{1}$ Universitas Putera Batam \\ tiurniari@gmail.com
}

\begin{abstract}
This study aims to determine what, who and how the shocked market in the Batam operate in accordance with research methodology used in research that is the method of evaluation research. The model used in this study is the CIPP evaluation, the model is analyzes the four dimensions of context dimension, input dimension, process dimension and product dimension. Batam city consists of 12 districts, there are only nine districts have 27 markets shocked. In this study, geographically dispersed market was dominated by Batu Aji sub-district with 10 markets in shock following Sekupang with five markets, while Sagulung four and Batam Kota had two shock markets. For District Nongsa, Batu Ampar, Bengkong, Sei Beduk, Lubuk Baja, each one market. The results of the evaluation obtained from this study is that the most needed by traders in the shock market is the attention and action of the local government. Attention in this regard is the support and proper facilities that can ultimately improve and develop the local economy concerned.
\end{abstract}

Keywords: Evaluation Research, Shocked Market

\begin{abstract}
ABSTRAK
Penelitian ini bertujuan untuk mengetahui apa, siapa dan bagaimana pasar kaget di kota Batam beroperasi sesuai dengan metodologi penelitian yang digunakan dalam penelitian yaitu metode riset evaluasi. Model yang dipakai dalam penelitian ini adalah model evaluasi CIPP yaitu model yang menganalisa empat dimensi yaitu dimensi konteks, dimensi input, dimensi proses dan dimensi produk. Kota Batam terdiri dari 12 kecamatan, hanya ada sembilan kecamatan memiliki 27 pasar kaget. Dalam penelitian ini, secara geografis penyebaran pasar kaget didominasi oleh kecamatan Batu Aji dengan 10 pasar kaget menyusul Sekupang dengan lima pasar, sementara Sagulung empat dan Batam Kota memiliki dua pasar kaget. Untuk District Nongsa, Batu Ampar, Bengkong, Sei Beduk, Lubuk Baja, masing-masing satu pasar. Hasil evaluasi yang diperoleh dari penelitian ini adalah bahwa yang paling dibutuhkan oleh pedagang di pasar kaget adalah perhatian dan tindakan dari pemerintah setempat. Perhatian dalam hal ini adalah dukungan dan fasilitas yang layak yang pada akhirnya bisa meningkatkan dan mengembangkan perekonomian daerah yang bersangkutan.
\end{abstract}

Kata Kunci: Riset Evaluasi, Pasar Kaget

\section{PENDAHULUAN}

Penduduk kota Batam didominasi oleh orang-orang pekerja dengan usia produktif. Waktu untuk berkerja berputar secara nilai ekonomis, baik pagi, siang, sore, maupun malam. Hal ini menuntut segala sesuatu harus efisien dan efektif dalam kehidupan sehari hari. Sesuatu yang sifatnya instan sekalipun itu tidak berkualitas masih masuk dalam daftar pertimbangan permintaan, apalagi kalau sesuatu itu berkualitas akan menuntun ke tingkat permintaan tinggi. Ibarat kata, kalau butuh buah tidak perlu ke pasar buah atau ke pasar pagi akan tetapi ada tersedia di pinggir jalan yang dilewati ketika pulang pergi kerja. Kondisi ini sangat dipahami oleh penjual maupun pembeli sebagai suatu peluang yang menjanjikan untuk dijadikan sumber pendapatan, sehingga tidak sulit menemukan pasar kecil-kecilan maupun pasar besar secara fisik diperkotaan maupun di pedesaan. (Kotler, 2002) Pasar adalah suatu tempat fisik di mana pembeli dan penjual berkumpul untuk mepertukarkan barang dan jasa. Sebuah pasar muncul lebih atau kurang spontan atau sengaja dibangun oleh interaksi manusia untuk memungkinkan pertukaran hak (kepemilikan) jasa dan barang.

Peraturan Presiden No 112 Tahun 2007, Pasar adalah area tempat jual beli barang dengan jumlah penjual lebih dari satu baik yang disebut sebagai pusat perbelanjaan, pasar tradisional, pertokoan, mall, plasa, pusat perdagangan maupun sebutan lainnya. Dari pengertian tersebut terdapat beberapa unsur pokok yaitu adanya penjual, pembeli, tempat dan waktu serta kesepakatan transaksi. Pasar yang demikian 
disebut juga sebagai pasar tradisional. Secara garis besar menurut para ahli, pasar adalah tempat yang digunakan manusia untuk pertemuan antara pembeli dan penjual yang ingin melakukan transaksi jual beli suatu barang ataupun jasa. Pasar juga dapat digunakan untuk menata keinginan serta kepentingan pambeli kepada penjual yang memiliki atuaran main yang baik bagi pihak pembeli maupun pihak penjual. Aturan tersebut ada dalam aturan tertulis dan ada dalam aturan tidak tertulis. Definisi ini dibuktikan dengan munculnya "pasar kaget".

Pasar kaget menurut bahasa resmi Bahasa Indonesia adalah (tidak baku) pasar sesaat yang terjadi ketika terdapat sebuah keramaian atau perayaan. Berdasarkan manajemen pengelolaan, pasar dibagi dua yaitu pasar tradisional dan pasar modern. Salah satu bentuk pasar tradisional adalah pasar kaget. Disebut pasar kaget karena adanya tiba-tiba. Pasar tradisional adalah pasar yang pelaksanaannya bersifat tradisional tempat bertemunya penjual pembeli, terjadinya kesepakatan harga dan terjadinya transaksi setelah melalui proses tawarmenawar harga. Biasanya pasar tradisional umumnya menyediakan berbagai macam bahan pokok keperluan rumah tangga, dan pasar ini biasanya berlokasi di tempat yang terbuka.

Pasar kaget sebenarnya sudah muncul sejak lama di luar kota Batam seperti di Jawa dan pulau lainnya. Tapi di Kota Batam fenomena pasar kaget baru trend sejak tahun
2013 atau tiga tahun terakhir ini. Ada yang menyebutnya pasar dadakan, pasar malam, dan ada juga yang menyebutnya dengan pasar tumpah. Munculnya peluang akan keberadaan pasar kaget ini tidak jauh beda dengan pasar malam yang sudah ada sejak dulu. Hanya saja kalau pasar malam berpindah-pindah per minggu atau per beberapa hari, sementara pasar kaget tidak tapi akan buka per minggu sebanyak tiga kali atau beberapa kali, tergantung tempat pasar kagetnya. Pasar Kaget atau pasar malam ini akan menjadi pemicu tumbuhnya perekonomian di daerah yang bersangkutan.

Seiring waktu dengan bertambahnya tuntutan terhadap pemenuhan kebutuhan hidup, maka pasar kaget mulai menjamur secara perlahan di Kota Batam. Jumlah pedagang dan pembeli semakin banyak, tempat berdagang semakin luas serta waktu transaksi semakin lama. Sementara jika ditarik kembali ke teori penentuan lokasi sebuah pasar, dibutuhkan beberapa faktor yang harus dipenuhi agar dapat tercipta lingkungan yang baik dan tertata rapih.

Kota Batam terdiri dari 12 kecamatan dan secara geografis 12 kecamatan ini tidak berada dalam satu pulau seperti yang terlihat pada Tabel 1 Sembilan kecamatan berada dalam satu pulau yaitu Dalam Pulau Batam sementara tiga kecamatan berada di luar pulau Batam dan tiga kecamatan ini di pulau yang berbeda-beda secara geografis.

Tabel 1. Kecamatan Di Pulau Batam

\begin{tabular}{|c|c|c|}
\hline No & Kec. Dalam Pulau Batam & Kec. Diluar Pulau Batam \\
\hline 1 & Kecamatan Batu Aji & 1. Kecamatan Belakang Padang \\
\hline 2 & Kecamatan Sagulung & 2. Kecamatan Galang \\
\hline 3 & Kecamatan Sungai Beduk & 3. Kecamatan Bulang \\
\hline 4 & Kecamatan Batam Kota & \\
\hline 5 & Kecamatan Batu Ampar & \\
\hline 6 & Kecamatan Bengkong & \\
\hline 7 & Kecamatan Nongsa & \\
\hline 8 & Kecamatan Lubuk Baja & \\
\hline 9 & Kecamatan Sekupang & \\
\hline
\end{tabular}

Sumber: BPS Batam 2015

Keberadaan pasar kaget ini menyebar hampir di semua kecamatan kecuali Kecamatan Lubuk Baja. Untuk saat ini, jumlah pasar kaget yang ada di Kota Batam adalah sebanyak 25 pasar kaget. Jumlah pasar kaget paling banyak berada di Kecamatan Batu Aji sebanyak sembilan pasar kaget, menyusul 
Kecamatan Sagulung sebanyak empat pasar dan Kecamatan Sekupang juga sebanyak empat pasar kaget. Kecamatan Batam Kota hanya memiliki dua pasar kaget. Sementara Kecamatan Batu Ampar, Kecamatan Sungai Beduk, dan Kecamatan Nongsa, masingmasing memiliki satu pasar kaget.

Ada satu kecamatan yaitu Lubuk Baja yang sama sekali tidak memiliki pasar kaget. Daerah Kecamatan Lubuk Baja sering disebuat dengan daerah Nagoya yang merupakan daerah perkotaan, dipenuhi dengan bangunan-bangunan yang dijadikan tempat usaha dan daerah perkantoran sehingga Kecamatan Lubuk Baja termasuk daerah bisnis yang ada di Batam meskipun daerah perumahan pun terdapat di beberapa Kelurahan sehingga tidak semua areal merupakan pusat bisnis.

Keberadaan pasar kaget ini tidak membatasi konsumennya dari berbagai segmen. Menurut Hermawan Kertajaya, segmentasi pasar adalah sebuah metode bagaimana memandang pasar secara kreatif. Menurut Philip Kotler segmentasi konsumen dilakukan berdasar pada satu atau lebih empat kriteria, yakni : (a) geografis, pasar dibagi menjadi unit-unit geografis yang berbeda seperti negara, wilayah, propinsi, kota, maupun lingkungan; (b) demografis, pasar dibagi menjadi kelompok berdasarkan peubah-peubah demografis seperti usia, ukuran keluarga, siklus hidup keluarga, jenis kelamin, penghasilan, pekerjaan, pendidikan, agama, ras, generasi, kewarganegaraan dan kelas sosial; (c) psikografis, pembeli dibagi menjadi kelompok berdasarkan kelas sosial, gaya hidup dan kepribadian; dan (d) perilaku, pembeli dibagi menjadi kelompok berdasarkan pengetahuan, sikap, pemakaian, maupun tanggapannya terhadap sesuatu. Semua jenis segmen berbelanja di pasar kaget yang terdaftar pada tabel berikut. Jam operasional pasar kaget ini beragam, ada yang beroperasi di pagi hari juga di sore hari. Tapi kebanyakan beroperasi di sore hari mulai pukul 15.00 hingga 22.00 malam hari. Masalah hari operasional juga beragam akan tetapi semuanya dari hari Senin hingga Sabtu kecuali pasar kaget Jodoh, buka dari hari Senin hingga hari Minggu.

Jenis pengunjung pasar kaget di Kota Batam beragam, tanpa memandang dari segmen tertentu, akan tetapi karena pasar kaget adalah bagian dari pasar tradisional seolah memberi kesan bahwa hanya orangorang dari segmen tertentu yang mengunjugi pasar kaget. Hal ini dibuktikan oleh penelitian secara diskriptif terjadi persaingan yang tidak seimbang antara pasar tradisional dan pasar modem. Dari 21 indikator persaingan bauran pemasaran 76 persen dikuasai oleh pasar modern (Purwanto 2012; 126). Sedikit sebagai gambaran tentang respon masyarakat terhadap pasar kaget yang diteliti oleh Syahrier (2015) mengemukakan bahwa dari segi tingkat pendapatan, masyarakat sebanyak 64 persen yang mengunjungi pasar kaget adalah yang berpenghasilan menengah keatas.

Oleh karena itu rumusan masalah sekaligus tujuan dari penelitian ini adalah untuk menganalisa apa, siapa dan bagaimana pasar kaget beroperasi di kota Batam. Istilah psikografis memiliki ide yang menggambarkan (grafik) faktor-faktor mengalisa psikologis (psycho) yang membentuk konsumen (Mowen, 2002:283). Namun dalam prakteknya, psikografis dipergunakan untuk mengukur gaya hidup konsumen dengan menganalisis aktivitas, minat dan opini (activities-interests, and opinion- AIO). Analisis psikografis adalah jenis riset konsumen yang menggambarkan segmen konsumen dalam hal bagaimana mereka hidup, bekerja, dan bermain (Mowen, 2002:282).

Konsumen secara tidak langsung telah menjadi media untuk membangun citra produk sehingga akan menguntungkan perusahaan. Adanya psikografis (gaya hidup) (psychographyc/life style) kepribadian (personality), yang semakin dinamis menyebabkan terjadinya perubahan yang cepat terhadap diri konsumen. Percepatan perubahan ini juga terjadi karena berbagai kemajuan di bidang teknologi, disamping itu juga karena tuntutan perkembangan jaman. Kemajuan teknologi terutama teknologi informasi telah menyebabkan lalu lintas arus informasi dan budaya tidak dapat lagi dicegah. Kuatnya budaya asing masuk telah membawa pengaruh terhadap kehidupan seseorang bahkan kehidupan suatu masyarakat/negara.

TINJAUAN PUSTAKA Segmentasi pasar 
Segmentasi pasar adalah suatu konsep yang sangat penting dalam kehidupan ini. Dalam kegiatan bisnis, segmentasi pasar digunakan untuk memilih pasar sasaran, mencari peluang, menggerogoti segmen pemimpin pasar, merumuskan pesan-pesan komunikasi, melayani lebih baik, menganalisis perilaku konsumen, dan mendesain produk (Kasali, 2005). Segmentasi konsumen dilakukan berdasar pada satu atau lebih empat kriteria, yakni :(a) geografis, pasar dibagi menjadi unit-unit geografis yang berbeda seperti negara, wilayah, propinsi, kota, maupun lingkungan; (b) demografis, pasar dibagi menjadi kelompok berdasarkan peubahpeubah demografis seperti usia, ukuran keluarga, siklus hidup keluarga, jenis kelamin, penghasilan, pekerjaan, pendidikan, agama, ras, generasi, kewarganegaraan dan kelas sosial; (c) psikografis, pembeli dibagi menjadi kelompok berdasarkan kelas sosial, gaya hidup dan kepribadian; dan (d) perilaku, pembeli dibagi menjadi kelompok berdasarkan pengetahuan, sikap, pemakaian, maupun tanggapannya terhadap sesuatu (Kotler, 2002).

\section{Pasar Tradisional}

Pasar tradisional adalah pasar yang dibangun dan dikelola oleh pemerintah, pemerintah daerah, swasta, badan usaha milik negara, dan badan usaha milik daerah termasuk kerjasama dengan swasta dengan tempat usaha berupa toko, kios, los dan tenda yang dimiliki/dikelola oleh pedagang kecil, menengah, swadaya masyarakat atau koperasi dengan usaha skala kecil, modal kecil dan dengan proses jual beli barang dagangan melalui tawar-menawar (Peraturan Menteri Perdagangan Nomor 53 Tahun 2008 tentang Pedoman Penataan dan Pembinaan Pasar Tradisional, Pusat Perbelanjaan dan Toko Modern Pasal 1 ayat 2). Pasar tradisional merupakan tempat bertemu antara penjual dan pembeli, melakukan transaksi secara langsung dengan adanya aktifitas tawar-menawar harga. Selain itu, pasar tradisional dianggap sebagai pasar basah karena keadannya yang cenderung tidak nyaman, kotor, kumuh, bahkan menjadi sumber kemacetan lalu lintas Salah satu karakteristik yang menonjol dari pasar tradisional adalah: 1 . Banyaknya pedagang yang menjual jenis barang dan jasa yang sama. 2. Harga barang relatif murah, namun kualitas dan kebersihan barang kurang diperhatikan. 3. Dalam mengelola usaha khususnya dalam menyediakan persediaan barang dagangan, para pedagang pasar berjalan sendiri-sendiri. 4. Perbedaan waktu aktifitas masing-masing pasar memberikan keuntungan bagi para bakul karena mereka dapat menjual barang dari satu pasar kemudian berpindah ke pasar lain dalam waktu satu hari. Tetapi ada juga bakul yang hanya berjualan di satu pasar.

\section{METODE PENELITIAN}

Untuk menganalisis respon segmen psikografis terhadap pasar kaget di kota Batam digunakan pendekatan kualitatif dengan metode riset evaluasi. Lebih sepesifiknya dengan evaluasi model CIPP dikembangkan oleh Stufflebeam, model CIPP 1971 (dari Ward Mitchell Cates, 1990), melihat kepada empat dimensi yaitu dimensi Konteks, dimensi Input, dimensi Proses dan dimensi Produk. CIPP merupakan sasaran evaluasi yang berupa komponen sebuah program kegiatan dan dipandang sebagai sebuah sistem. Apabila evaluator menentukan CIPP sebagai model yang digunakan untuk mengevaluasi program, maka program di analisis berdasarkan komponen-komponen dengan beberapa pertanyaan.

\section{HASIL PENELITIAN DAN PEMBAHASAN}

Kota Batam Terdiri dari 12 Kecamatan, dalam wilayah Pulau Batam sendiri ada sembilan kecamatan dan selebihnya diluar wilayah Pulau Batam. Pada Tabel 3 berikut ini bisa dilihat daftar kecamatan apa saja yang berada dalam pulau Batam. Selanjutnya, objek penelitian ini terdiri kecamatan yang berada dalam pulau Batam. Masyarakat Batam yang rata-rata berasal dari luar Kota Batam atau kaum pendatang mereka berasal dari berbagai ragam suku/etnis,serta budaya yang berbeda, yang sekarang menjadi penduduk Kota Batam, karakteristiknya sangat beragam hal 
ini tampak dalam ciri perumahannya maupun strata sosial, seperti kampung Aceh, kampung Jawa, kampung Bugis, kampung Melayu, kampung Cina dan lain-lain. Dengan adanya perbedaan suku/etnis tersebut mereka saling menghormati tidak mempermasahkan status asalnya, mereka sudah menjadi satu kesatuan masyarakat Kota Batam sebagai masyarakat yang sopan santun, disiplin, beradap serta berbudaya tinggi. Seiring dengan perkembangan Kota Batam kehidupan mereka sudah membaur. Ciri ciri pasar kaget di kota Batam secara umum adalah sama, tidak jauh berbeda antara yang satu dengan yang lain. Diantaranya adalah:

1. Tidak beroperasi tiap hari akan tetapi paling tidak beroperasi antara satu sampai tiga kali dalam seminggu, terkecuali dengan pasar kaget PCI di Tiban yang beroperasi hanya pada akhir dan awal bulan. Hal ini dugaan sementara kemungkinan berhubugan dengan tanggal gajian para karyawan.

2. Setiap pasar kaget memperjualbelikan kebutuhan sehari-hari terutama sembako.

3. Setiap pasar kaget memperjualbelikan pakaian, sepatu dan kebutuhan lainnya yang sifatnya masih baru tapi skala harga yang sangat terjangkau oleh semua lapisan masyarakat.

4. Setiap pasar kaget memperjual-belikan barang-barang second atau bekas pakai. Istilah orang-orang Batam menyebutnya "barang seken". Barang seken adalah barang-barang bekas pakai dari negara Singapura dan Malaysia. Jenis barang seken ini beragam; pakaian, mainan anak-anak, peralatan dapur, buku-buku umum, tas, sepatu, elektronik, dan perkakas rumah.

5. Setiap pasar kaget beroperasi mulai sore hingga malam hari sekitar pkl 15.00 hingga 22.00

6. Setiap lokasi pasar kaget berada dipinggir jalan raya (jalan yang dilalui oleh banyak orang).

7. Di setiap pasar kaget tersedia hasil kebun baru dipanen (asli hasil kebun dari Batam) untuk diperjualbelikan.

8. Pengunjung pasar kaget secara umum tidak dibatasi oleh segmen konsumen tertentu seperti; orang berpenghasilan rendah, sedang, dan kaya, wanita, pria, ibu-ibu, remaja, pekerja, ibu rumah tangga, dan lain-lain.

\section{SIMPULAN}

Berdasarkan hasil penelitian dan pembahasan, maka dapat ditarik kesimpulan sebagai berikut:

1) Ada perbedaan persepsi antar para pemangku kepentingan tentang sistem yang terbaik dalam optimalisasi ekonomi Batam agar segera diselesaikan. Penting agar semua stakeholder terkait tentang permasalahan ini mau duduk bersama untuk menyelesaikan persoalan ekonomi yang ada di batam;

2) Pemerintah pusat harus menggunakan pendekatan dari bawah ke atas untuk menampung aspirasi dari para pemangku kepentingan yang paling sering bersentuhan dengan permasalahan yang ada.

\section{Tabel 3. Daftar Kecamatan Di Pulau Batam}

\begin{tabular}{l|l|l}
\hline No & Kecamatan Dalam Pulau Batam & Kecamatan Diluar Pulau Batam \\
\hline 1 & Kecamatan Batu Aji & 1. Kecamatan Belakang Padang \\
2 & Kecamatan Sagulung & 2. Kecamatan Galang \\
3 & Kecamatan Sungai Beduk & 3. Kecamatan Bulang \\
4 & Kecamatan Batam Kota & \\
5 & Kecamatan Batu Ampar & \\
6 & Kecamatan Bengkong & \\
7 & Kecamatan Nongsa & \\
8 & Kecamatan Lubuk Baja & \\
9 & Kecamatan Sekupang & \\
\hline \multicolumn{2}{|c}{ Sumber: BPS Batam 2015 }
\end{tabular}


Pada Tabel 4 berikut, keberadaan pasar kaget yang berada di sembilan kecamatan ini tergolong dalam kategori banyak, hal ini terjadi bukan tanpa alasan. Hasil survei peneliti menemukan jumlah pasar kaget hingga Desember 2016 sebanyak 27 pasar, berikut distribusi lokasinya.

Tabel 4 Lokasi Pasar Kaget Di Kota Batam Berdasarkan Kecamatan:

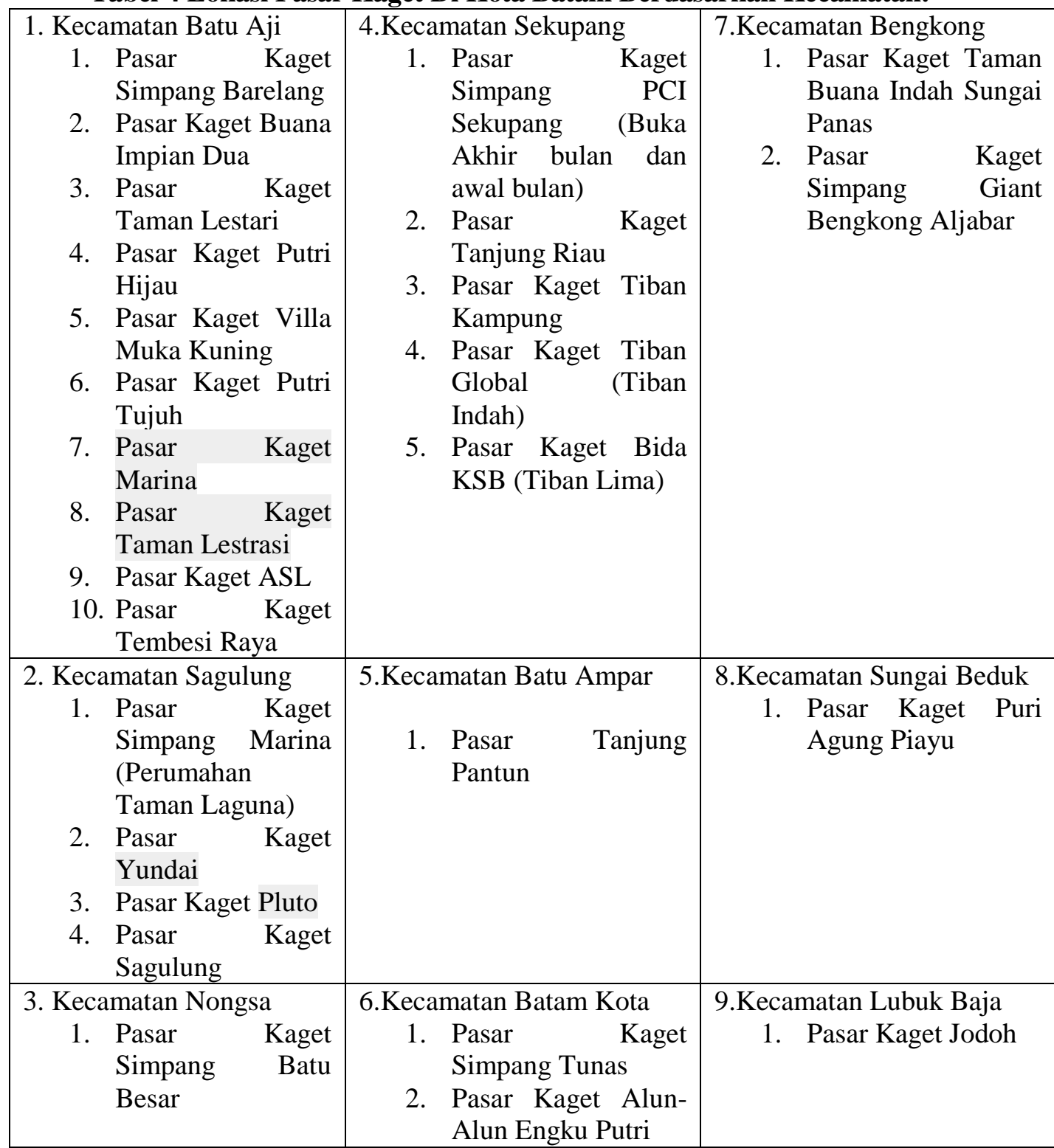

Sumber: Hasil survei peneliti di lapangan (Desember 2016).

Lahirnya pasar kaget bukan berarti karena tidak ada pasar tradisional atau dikarenakan sedikit jumlah pasar di kota Batam. Sebagai perbandingan, jumlah pasar yang dibina dan terdaftar di Kota batam sebanyak 41 pasar untuk jumlah penduduk 1.300 .000 jiwa. Sebanyak 36 pasar dikelola oleh pihak swasta dan sisanya yaitu lima pasar dikelola oleh pihak pemerintah. Lima pasar tersebut berada di kecamatan; Sagulung, Lubuk Baja, Belakang Padang, Nongsa, dan Batu Aji.
Sementara untuk jenis pasar tradisonal, berdasarkan data dari Dinas Pasar Kota Batam, bahwa jumlah pasar tradisional berjumlah 29. Semua pasar tradisional ini dikelola oleh pihak swasta. Keberadaan pasar tradisional ini didominasi di wilayah kecamatan Batam Kota sebanyak enam pasar, menyusul kecamatan Sagulung sebanyak lima pasar, berikutnya kecamatan Batu Aji dan Lubuk Baja masing-masing sebanyak empat pasar. Kecamatan Bengkong dan kecamatan Sekupang masing-masing empat pasar 
kemudian Nongsa sebanyak dua dan terakhir masing-masing Batu Ampar dengan Belakang Padang sebanyak satu pasar tradisional. Susunan mengapa terbanyak di Kecamatan Batam Kota sementara Batam Kota tidak memiliki jumlah penduduk sebanyak kecamatan Batu Aji atau Sagulung, akan dibahas dalam penelitian berikutnya. Akan tetapi sebagai gambaran bahwa Kecamatan Batam Kota adalah salah satu kecamatan tua di Batam dibandingkan dengan kecamatan lainnya.

\begin{tabular}{|c|c|c|c|c|c|}
\hline \multicolumn{6}{|c|}{ DAFTAR NAMA PASAR TRADISIONAL DI KOTA BATAM TH. 2014} \\
\hline No & $\begin{array}{l}\text { NAMA PASAR / PUSAT } \\
\text { PERBELANJAAN }\end{array}$ & ALAMAT & KELURAHAN & KECAMATAN & DI BAGUN OLEH \\
\hline 1 & Pasar Mega Legenda & Jl. Sudirman - Batam Centre & Baloi Permai & Batam Kota & Swasta \\
\hline 2 & Pasar Nasa & Il. Abulyatama, Ruko nasa - Batam Centre & Belian & Batam Kota & Swasta \\
\hline 3 & Pasar Mitra Raya & Perum. Mitra Raya - Batam Centre & Teluk Tering & Batam Kota & Swasta \\
\hline 4 & Pasar Aviari & Il. Batu Aji - Batam & Buliang & Batu Aji & Swasta \\
\hline 5 & Pasar Fanindo Tanjung Uncang & Il. Sukamto Tig Uncang - Batam & Batu Aji & Batu Aji & Swasta \\
\hline 6 & Pasar Tanjung Pantun & Il. Raja Ali Haji - Jodoh Batam & Sei. Jodoh & Batu Ampar & Swasta \\
\hline 7 & Pasar Cahaya Garden & Perm Cahaya Garden - Bengkong Sadai Batam & Sadai & Bengkong & Swasta \\
\hline 8 & Pasar Angkasa Bengkong & Bengkong Harapan Baru - Batam & Bnkg Harapan Baru & Bengkong & Swasta \\
\hline 9 & Pasar Bengkong Harapan & Bengkong Harapan Baru - Batam & Bnkg Harapan Baru & Bengkong & Swasta \\
\hline 10 & Pasar Penuin Centre & Il. Penuin - Penuin Batam & Batu Selicin & Lubuk Baja & Swasta \\
\hline 11 & Pasar Toss 3000 & Il. Raja Ali Haji - Jodoh Batam & Lubuk Baja Kota & Lubuk Baja & Swasta \\
\hline 12 & Pasar Avava Market & Il. Raja Ali Haji - Jodoh Batam & Lubuk Baja Kota & LubukBaja & Swasta \\
\hline 13 & Pasar Lai lai & Telaga Punggur - Batam & Telaga Punggur & Nongsa & Swasta \\
\hline 14 & Pasar Sagulung & Il. Suprapto - Sagulung Batam & Sagulung Kota & Sagulung & Swasta \\
\hline 15 & Pasar PJB & Il. Sukamto - Batam & Sagulung Kota & Sagulung & Swasta \\
\hline 16 & Pasar Sentosa Perdana & Il. Sukamto-Batam & Tembesi & Sagulung & Swasta \\
\hline 17 & Pasar Rakyat Tembesi & Tembesi-Batam & Tembesi & Sagulung & Swasta \\
\hline 18 & Pasar Tiban Centre & Il. Gajah Mada - Sekupang Batam & Tiban Indah & Sekupang & Swasta \\
\hline 19 & Pasar Cipta Puri & Il. Gajah Mada - Sekupang Batam & Tiban Baru & Sekupang & Swasta \\
\hline 20 & Pasar Taman Raya & Batam Centre & Belian & Batam Kota & Swasta \\
\hline 21 & Pasar Merlion & Il. Diponegoro Tjg Uncang & Tanjung Uncang & Batu Aji & Swasta \\
\hline 22 & Pasar Nasa & Sagulung - Batam & Sungai Binti & Sagulung & Swasta \\
\hline 23 & Pasar Botania & Taman Raya Dekat SMA 3 - Batam Centre & Belian & Batam Kota & Swasta \\
\hline 24 & Pasar Grand Land & Perum Grand Land - Batam Centre & Teluk Tering & Batam Kota & Swasta \\
\hline 25 & Pasar Sungai Harapan & Il. KH.Ahmad Sei Harapan Sekupang Batam & Sungai Harapan & Sekupang & Swasta \\
\hline 26 & Pasar Hang Tua & Batu Besar - Nongsa Batam & Batu Besar & Nongsa & Swasta \\
\hline 27 & Pasar Belakang Padang & Belakang Padang & Taman Sari & Belakang Padang & Swasta \\
\hline 28 & Pasar Dapur 12 & Dapur 12 Tjg Uncang & Sungai Pelenggut & Sagulung & Swasta \\
\hline 29 & Pasar IndukJodoh & Il. Duyung-Jodoh Batam & Tg. Uma & LubukBaja & Swasta \\
\hline
\end{tabular}

Sumber: http://skpd.batamkota.go.id

\section{Pasar Kaget di Kecamatan Batu Aji}

Teristimewa di kecamatan Batu Aji, dipadati sebanyak 10 pasar kaget antara lain; Pasar Kaget Simpang Barelang, Pasar Kaget Buana Impian Dua, Pasar Kaget Taman Lestari, Pasar Kaget Putri Hijau , Pasar Kaget Villa Muka Kuning, Pasar Kaget Putri Tujuh, Pasar Kaget Marina, Pasar Kaget Taman Lestrasi, dan Pasar Kaget ASL. Secara psikografis dari sisi kelas sosial, karakteristik yang berbeda dan keinginan orang-orang dalam kelas yang berbeda menyatu di pasar kaget ini. Pedagang tidak menggunakan kelas sosial untuk membagi pasar mereka dalam jual beli. Konsumen dari pejalan kaki hingga mobil mewah membaur. Untuk variabel personalitas pada segmen psikografis, pedagang sama sekali tidak mencoba untuk membagi pasar berdasarkan kepribadian, tidak ada pengetahuan bahwa kepribadian mempengaruhi produk dan merek yang akan dibeli konsumen, karena inilah namanya pasar kaget bagian dari pasar tradisional. Variabel berdasarkan gaya hidup adalah metode terbaru dalam mengenali aspek dalam kehidupan orang-orang dalam melakukan pembelian. Akan tetapi di pasar kaget, semua terjadi karena aktifitas yang serba sibuk, jarang ada pemikiran berkunjung ke pasar kaget karena hedonis, minat, dan opini. Dengan jumlah penduduk yang padat yaitu sebanyak 119.706 jiwa, jenis sarana perekonomian penduduk tidak berbeda dengan kecamatan yang lain. Pada tabel berikut, jenis usaha yang mendominasi adalah pertokoan yang kebanyakan berada dalam bentuk bangunan rumah toko. Sementara jenis pasar swalayan hanya berjumlah enam dan itupun jenis swalayan ala kadarnya, kecuali satu buah hypermart. 
Tabel 7 Jenis Usaha Penduduk Kecamatan Batu Aji

\begin{tabular}{|c|c|c|c|c|c|c|}
\hline \multirow{2}{*}{ NO } & \multirow{2}{*}{$\begin{array}{l}\text { JENIS SARANA } \\
\text { PEREKONOMIAN }\end{array}$} & \multicolumn{4}{|c|}{ KELURAHAN } & \multirow{2}{*}{ JUMLAH } \\
\hline & & $\begin{array}{c}\text { Bukit } \\
\text { Tempayan }\end{array}$ & Buliang & Kibing & $\begin{array}{c}\text { Tg. } \\
\text { Uncang }\end{array}$ & \\
\hline 1 & Koperasi & 8 & 3 & 2 & 1 & 14 \\
\hline 2 & Bank & 2 & 5 & 1 & 8 & 16 \\
\hline 3 & Mini Market & 6 & 14 & 54 & 4 & 78 \\
\hline 4 & Pasar Swalayan & 1 & 2 & 1 & 2 & 6 \\
\hline 5 & Toko & 128 & 248 & 189 & 450 & 1.015 \\
\hline 6 & Wartel / Kios Phone & 15 & 43 & 10 & 6 & 74 \\
\hline
\end{tabular}

2. Pasar Kaget Di Kecamatan Sagulung

Kecamatan Sagulung terdiri dari enam kelurahan dengan total jumlah penduduk 165.517 jiwa. Karakteristik kecamatan Sagulung tidak jauh beda dengan kecamatan Batu Aji karena wilayahnya bertetangga. Hanya saja, kecamatan Sagulung termasuk salah satu kecamatan terbelakang di Kota Batam. Hal ini dibuktikan dengan masih banyak penduduk tinggal di pemukiman yang kurang layak atau sering disebut dengan istilah rumah liar (ruli). Adapun perumahan yaitu dengan jenis tipe sangat sederhana dan sederhana. Ruli-ruli tersebut tumbuh terutama akibat kemampuan ekonomi finansial dari sebagian pendatang yang rendah sehingga menyebabkan mereka tidak memiliki kemampuan cukup untuk mendapatkan fasilitas bermukim secara formal. Ruli yang cenderung tumbuh meluas pada skala lingkungan telah banyak menempati kawasankawasan yang semestinya berfungsi lindung. Ruli ini bisa jadi dasar pendukung lahirnya pasar kaget, akan tetapi walau kenyataan seperti diatas, jumlah pasar kaget di kecamatan Sagulung hanyalah sebanyak empat pasar kaget.Secara psikografis dari variabel kelas sosial, karakteristik yang sama dan keinginan orang-orang dalam kelas yang sama menyatu di pasar kaget ini. Pemasar tidak menggunakan kelas sosial untuk membagi pasar mereka dalam jual beli. Pada variabel personalitas, pemasar, sama sekali tidak mencoba untuk membagi pasar berdasarkan kepribadian, tidak ada pengetahuan bahwa kepribadian mempengaruhi produk dan merek yang akan dibeli konsumen, karena inilah namanya pasar kaget bagian dari pasar tradisional. Variabel berdasarkan gaya hidup adalah metode terbaru dalam mengenali aspek dalam kehidupan orang-orang dalam melakukan pembelian. Akan tetapi di pasar kaget, semua terjadi karena aktifitas yang serba sibuk, jarang ada pemikiran berkunjung ke pasar kaget karena hedonis, minat, dan opini.

\section{Pasar Kaget Di Kecamatan Batam Kota \\ Oleh masyarakat Batam, Kecamatan} Batam Kota lebih dikenal dengan istilah Batam Center. Di Kecamatan inilah terletak pusat pemerintahan Kota Batam, alunalun, dan Masjid Raya Batam. Mega Wisata Ocarina juga terletak di Kecamatan ini. Lokasinya yang strategis di tengah-tengah Pulau Batam membuat Kecamatan Batam Kota berkembang pesat menjadi kawasan industri dan pemukiman yang ramai. Kecamatan Batam Kota memiliki tujuh kelurahan dengan jumlah penduduk 123.972 jiwa. Wilayah Batam Kota diperuntukan bagi CBD dengan ditunjang oleh kegiatan campuran seperti restoran, hiburan, permukiman, dan perkantoran. Pertumbuhan penduduk di kecamatan Batam Kota setiap tahunnya meningkat, mengingat Kecamatan Batam Kota adalah pusat pemerintahan Kota Batam dan salah satu pusat industri di Kota Batam, pembangunan di Kecamatan Batam Kota sangat meningkat khususnya pembangunan perumahan. Secara psikografis dari variabel kelas sosial penduduk Batam Kota, karakteristik yang sangat berbeda dan keinginan yang berbeda dari penduduk kecamatan yang lainnya. Orang-orang dalam kelas menengah keatas mendominasi, dipadati perumahan elit, mobil-mobil mewah, mall 
mewah. Sangat jelas pemasar menggunakan kelas sosial untuk membagi pasar mereka. Walau demikian masih tetap terdapat sebanyak dua pasar kaget di kecamatan ini. Pada variabel personalitas, pemasar, bisa dikatakan tidak mencoba membagi pasar berdasarkan kepribadian, tidak ada bahwa kepribadian mempengaruhi produk dan merek yang akan dibeli konsumen, karena inilah namanya pasar kaget bagian dari pasar tradisional. Variabel berdasarkan gaya hidup adalah metode terbaru dalam mengenali aspek dalam kehidupan orang-orang dalam melakukan pembelian. Akan tetapi di pasar kaget, semua terjadi karena aktifitas yang serba sibuk, jarang ada pemikiran berkunjung ke pasar kaget karena hedonis, minat, dan opini.

\section{Pasar Kaget Di Kecamatan Sekupang}

Wilayah Kecamatan Sekupang terdiri dari pulau besar dan kecil dengan penyebaran penduduk tidak merata di pulau yang berpenghuni sementara ada sebahagian wilayah pulau yang sulit untuk dijangkau. Kecamatan Sekupang memiliki penduduk sebanyak 123.972 jiwa dengan lima pasar kaget. Secara geografis, wilayah Kecamatan Sekupang dominan berada di Pulau Batam. Enam kelurahan yang ada di Kecamatan Sekupang berada di Pulau Batam dan hanya Kelurahan Tanjung Riau yang tersebar di beberapa pulau. Sebagian besar wilayah Kecamatan Sekupang berupa dataran. Tabel berikut ini menjelaskan beradaan jumlah penduduk kecamatan Sekupang berdasarkan kelurahan masing-masing. Keberadaan pasar kaget di Kecamatan Sekupang terdiri dari lima pasar kaget yang menyebar di tujuh kelurahan. Karakteristik pasar kaget ini tidak berbeda dari pasar kaget yang ada di kecamatan lainnya. Jenis usaha di Kecamatan Sekupang beragam mulai dari perusahaan perkapalan, manufakturing, banyak perkantoran instansi pemerintah juga usaha pertanian dan perikanan.

Keberadaan lima jumlah pasar kaget pada karakteristik penduduk yang beragam dari segi kelas sosial, personalitas, dan gaya hidup sangat wajar karena tidak akan ditemukan di Kecamatan Sekupang yang namanya super market dan sejenisnya. Untuk menutupi kebutuhan penduduk kelas sosial, personalitas dan gaya hidup hedonis, semua berpusat di Nagoya dan Batam Center.

5. Pasar Kaget Di Kecamatan
Bengkong
Kecamatan Bengkong bebatasan
dengan Kecamatan Batam Kota di sebelah tenggara dan dengan Kecamatan Batu Ampar di sebelah barat laut, Kecamatan Bengkong mempunyai lima kelurahan dengan total jumlah penduduk 103.398 jiwa. Keberadaan pasar kaget di Kecamatan Bengkong sebanyak dua pasar kaget yaitu, Pasar Kaget Taman Buana Indah Sungai Panas dan Pasar Kaget Simpang Giant Bengkong Aljabar. Kecamatan Bengkong merupakan wilayah yang terkonsentrasi sebagai daerah pemukiman sehingga industri Pariwisata tidak berkembang dengan baik. Namun diakhir tahun 2009 Pariwisata di Kecamatan Bengkong mulai memperlihatkan kemajuan yang cukup baik. Hal ini ditandai dengan dibukanya Taman Mega Wisata "OCARINA" yang menyediakan berbagai fasilitas hiburan wisata yang lengkap bagi wisatawan lokal maupun luar negri dan ditambah telah dibuka " WATERBOOM" pada tahun 2012. Karakteristik penduduk Bengkong tidak jauh berbeda dengan Batu Aji, secara psikografis dari variabel kelas sosial, rata-rata kelas menengah ke bawah. Minat beli akan sesuatu adalah karena kebutuhan. Keberadaan hanya dua lokasi pasar kaget dikarenakan tersedianya sejumlah pasar tradisional yang sangat terjangkau lengkap.

\section{Kecamatan Batu Ampar}

Kecamatan Batu Ampar merupakan salah satu Kecamatan dengan penduduk yang cukup padat sebanyak 87.962 jiwa. Terdiri dari empat kelurahan yaitu Tanjung Sengkuang, Sungai Jodoh, Batu Merah dan Kampung Seraya dengan luas Kecamatan $39.998 \mathrm{~km} 2$ yang kesemuanya berada di Pulau Batam. Kecamatan Batu Ampar selain merupakan daerah padat penduduk juga daerah perdagangan sehingga mayoritas penduduk bermata pencaharian sebagai pedagang ataupun pengusaha. Selain itu Kecamatan Batu Ampar juga ada daerah industri berat dan ringan yang terdapat di Kelurahan Tanjung Sengkuang, dengan 28 Perusahaan besar dan 25 perusahaan kecil namun masih ada segelintir yang menjadikan laut sebagai mata pencaharian dimana masih 
terdapat 52 rumah tangga yang bergerak di sektor perikanan laut dan 5 rumah tangga yang bergerak di budidaya laut yang mampu menghasilkan 316 ton dengan nilai produksi perikanan mencapai $\mathrm{Rp} 1,2$ Triliun. Kecamatan Batu Ampar pun di penuhi dengan toko-toko yang menjual berbagai barang dalam dan luar negeri serta hotel-hotel berstandar internasional yang di kelilingi oleh pusat perbelanjaan yang ramai sehingga cocok untuk berusaha di bidang perdagangan. Wilayah Batu Ampar diperuntukan bagi industri yang berhubungan dengan perminyakan, pada kenyataannya area Batu Ampar cukup padat berisi kegiatan industri.

Untuk analisis segmen psikografis di Kecamatan Batu Ampar terhadap pasar kaget sama seperti analisis di kecamatan lainnya, keberadaan pasar kaget di Batu Ampar hanya berada di satu lokasi. Penduduk Batu Ampar yang cukup padar tapi hanya memiliki satu lokasi pasar kaget dikarenakan berdekatan dengan lokasi pasar induk Batam yang berada di Pasar Jodoh. Untuk pasar kaget, semua lapisan masyarakat tidak memandang variabel kelas sosial, gaya hidup dan personalitas belanja di pasar induk Jodoh.

\section{Kecamatan Nongsa}

Kecamatan Nongsa secara geografis terdiri daerah pesisir/hinterland, dengan kriteria tersebut maka kecamatan ini mempunyai potensi yang baik untuk di kembangkan usaha seperti budi daya laut, wisata bahari. Penduduk asli yang sebagian besar bermata pencaharian sebagai Nelayan Tradisional. Kecamatan Nongsa terletak pada sebelah timur laut dari wilayah pulau Batam atau wilayah Barelang dengan posisi 1.000 1.18 lintang utara dan 104.000 - 104.150. Dengan batas wilayah sebagai berikut; Sebelah Utara: Laut Singapura. Sebelah Selatan: Kec. Galang dan Bulang Sebelah Timur: Laut dan Kabupaten Bintan. Sebelah Barat: Kec. Batuampar, Batam Kota, Sungai Beduk dan Bengkong.

Permukaan tanah di kecamatan ini pada umumnya dapat digolongkan datar dengan beberapa variasi perbukitan rendah dengan ketinggian maksimum 60 meter di atas permukaan laut, terdapat juga sungai kecil dengan aliran air yang sangat pelan serta semak belukar yang diselingi hutan muda pada hulunya, sementara pada bagian bibir ditumbuhi mangrove (hutan bakau) muda yang kian hari makin menipis seiring dengan pergeseran fungsi dari lahan tersebut, yang banyak dipengaruhi perkembangan ekonomi di Kota Batam. Pertumbuhan jumlah penduduk diwilayah Kecamatan Nongsa pada khususnya dan Kota Batam pada umumnya tidak tumbuh secara natural (alami). Akan tetapi pertumbuhannya disebabkan oleh migrasi baik lokal maupun migrasi antarpulau. Jumlah penduduk Kecamatan Nongsa per Juli 2014 sebanyak 57.601 jiwa. Variabel kelas sosial, gaya hidup dan personalitas belanja di pasar kaget wilayah Nogsa, tidak ada perbedaan.

\section{Kecamatan Sungai Beduk}

Kecamatan Sungai Beduk dengan jumlah penduduk 88.858 terdiri dari bagian pulau Batam dan pulau-pulau kecil. Penduduknya banyak akan tetapi keberadaan pasar kaget di daerah ini hanya satu. Ada dua pulau telah berpenghuni dan sisanya tiga pulau sementara belum berpenghuni. Penyebaran penduduk yang tidak merata. Kecamatan Sungai Beduk berbatasan dengan : Sebelah Utara: Nongsa dan Batam Kota Sebelah Selatan : Bulang dan Galang Sebelah Barat: Batu Aji dan Sagulung Sebelah Timur: Nongsa. Piramida Penduduk Berdasarkan Umur di Kecamatan Sungai Beduk Tahun 2010 (SP2010) Perubahan Jumlah penduduk di Kecamatan Sungai Beduk juga di pengaruhi oleh datang dan perginya para pekerja yang ada di Muka Kuning karena sebagian besar dari mereka di datangkan dari luar daerah terutama yang berumur 20-24 tahun untuk memenuhi kebutuhan tenaga kerja di kawasan industri terbesar di Kota Batam ini. Penduduk di Kecamatan Sungai Beduk didominasi oleh penduduk usia produktif.

Kecamatan Sungai Beduk memiliki satu kawasan industri yang sangat luas yaitu Muka Kuning, diperuntukan industri dengan tingkat pencemaran sangat rendah. Dibandingkan dengan wilayah industri lainnya, wilayah Batamindo-Muka Kuning ini paling baik. Penataan blok massa bangunan, zoning, sirkulasi transportasi, dan penataan lingkungan sangat baik. Berdasarkan karakteristik penduduk secara kelas sosial, personalitas, dan gaya hidup tidak berbeda dengan kecamatan Bengkong. Secara psikografis, minat beli akan sesuatu oleh masyarakat adalah karena kebutuhan. Keberadaan hanya dua lokasi pasar kaget 
dikarenakan tersedianya sejumlah pasar tradisional yang sangat terjangkau lengkap.

Jumlah lokasi pasar kaget di kecamatan ini hanya satu yaitu pasar kaget Puri Agung Piayu. Pengunjung pasar kaget di Puri Agung Piayu tidak berhubungan dengan karakteristik penduduk dari sisi psikografis.

\section{Kecamatan Lubuk Baja}

Daerah Kecamatan Lubuk Baja yang dihuni sebanyak 94.249 jiwa merupakan pusat perbelanjaan di Kota Batam, semua jenis barang mewah hingga barang tiruan tersedia. Kecamatan ini berbatasan langsung dengan Kecamatan Batu Ampar di sebelah utara, berbatasan dengan Kecamatan Batam Kota sebelah Selatan, berbatasan dengan Kecamatan Sekupang dan Laut Singapura di sebelah barat dan berbatasan dengan Kecamatan Batam Kota dan Kecamatan Bengkong di sebelah Timur.

Ada satu wilayah di kecamatan Lubuk Baja yaitu Nagoya yang disebut sebagai pusat berbelanja di Kota Batam, kegiatan utamanya adalah komersil dan campuran dengan ditunjang oleh permukiman yang tersebar merata disekitarnya. Kondisi ini diperkuat dengan pola penataan bangunan yang relatif dekat antar satu dengan yang lainnya, sehingga memudahkan bagi pengunjung untuk mencapainya. Secara umum keberhasilan Nagoya sebagai suatu kawasan komersil adalah karena tumbuh secara alami dengan pola orientasi pedestrian. Keberadaan diatas membuat Kecamatan Lubuk Baja hanya memiliki satu pasar kaget yang satu lokasi dengan pasar induk kota Batam.

Kecamatan Lubuk Baja juga dikenal sebagai pusat perdagangan dan jasa di Kota Batam, hal ini tercermin dari terus tumbuhnya sarana perekonomian yang ada di kawasan ini. Hal ini kemungkinan besar yang menjadikan ketiadaan pasar kaget di kecamatan Lubuk Baja. Pada tahun 2013 terdapat 43 buah kantor bank umum, 21 kantor bank perkreditan rakyat, 10 mall, 42 mini market dan 81 perusahaan perjalanan umum. Sarana Perekonomian disektor Keuangan di Kecamatan Lubuk Baja Tahun 2013. Sarana Keuangan Jumlah (1) (2) Kantor Bank 64 Money Change 50 Pegadaian 11 Asuransi 20 Sumber: Pengamatan Lapangan Kawasan Kecamatan Lubuk Baja juga terkenal sebagai pusat perbelanjaan dan memegang peranan penting bagi kemajuan perekonomian Kota
Batam, Berbagai macam pusat perbelanjaan telah dibangun guna memberikan kepuasan bagi konsumen dari berbagai daerah dan negara. Sedangkan untuk kegiatan perdagangan lokal juga di fasilitasi dengan tersedianya pasar tradisional dan modern. PERE Kelurahan Lubuk Baja Kota dan Kelurahan Batu Selicin merupakan kawasan perdagangan tersibuk di kecamatan ini, dimana terdapat 10 buah mall/pusat perbelanjaan dan 6 buah pasar. Sarana Perekonomian disektor Perdagangan di KecamatanLubuk Baja Tahun 2013. Sarana Perekonomian Jumlah Mall 10 Pasar 8 Mini Market 42 Pujasera 7 Sumber: Pengamatan Lapangan Selain sektor perdangangan sektor jasa dan hiburan juga menunjukkan pertumbuhan yang sangat positif diwilayah ini. Sarana Perekonomian disektor Jasa \& Hiburan di Kecamatan Lubuk Baja Tahun 2013.

Hal yang melekat pada diri manusia menyebabkan manusia mempunyai hasrat, kebutuhan dan keinginan. Ketiga hal tersebut merupakan hakekat kehidupan manusia. Hasrat, kebutuhan dan keinginan tidak dapat dipisahkan dari kehidupan manusia. Manusia selalu berusaha untuk mewujudkan hasratnya, memenuhi kebutuhan dan keinginannya. Ketiganya akan terwujud dalam diri seseorang bila orang tersebut mempunyai kemampuan untuk mewujudkannya. Berbagai keuntungan dengan terpuaskannya kebutuhan konsumen, diantaranya konsumen bila akan membeli ulang maka konsumen tidak kesulitan untuk mencari produk yang cocok dengan kebutuhannya. Konsumen dapat menjadi media promosi yang efisien dan efektif. Melalui komunikasi yang terjadi sesama konsumen, konsumen baik yang puas maupun tidak puas akan cenderung memberi tahu kepada yang lain tentang apa yang dialaminya setelah ia membeli suatu produk. Konsumen secara tidak langsung telah menjadi media untuk membangun citra produk sehingga akan menguntungkan perusahaan.

Adanya psikografis (gaya hidup) (psychographyc/life style) kepribadian (personality), yang semakin dinamis menyebabkan terjadinya perubahan yang cepat terhadap diri konsumen. Percepatan perubahan ini juga terjadi karena berbagai kemajuan di bidang teknologi, disamping itu juga karena tuntutan perkembangan jaman. 
Kemajuan teknologi terutama teknologi informasi telah menyebabkan lalu lintas arus informasi dan budaya tidak dapat lagi dicegah. Kuatnya budaya asing masuk telah membawa pengaruh terhadap kehidupan seseorang bahkan kehidupan suatu masyarakat/negara.

\section{SIMPULAN}

Kota Batam terdiri dari 12 kecamatan, delapan kecamatan diantaranya terpencar sebanyak 27 pasar kaget. Secara geografis, semua pasar kaget tersebut berada dalam wilayah Pulau Batam. Penyebaran pasar kaget didominasi wilayah Kecamatan Batu Aji dengan 10 pasar kaget menyusul Kecamatan Sekupang dengan lima pasar kaget, sementara Kecamatan Sagulung sebanyak empat pasar kaget dan Kecamatan Batam Kota sebanyak dua pasar kaget. Untuk Kecamatan Nongsa, Batu Ampar, bengkong, Sei Beduk, masingmasing satu pasar kaget, dan yang terakhir kecamatan Lubuk Baja dengan satu pasar kaget. kepintaran manusia menciptakan teknologi dan komunikasi mendorong hasrat manusia akan kebutuhan dan keinginan semakin tanpa batas. Ketiga hal tersebut merupakan hakekat kehidupan manusia. Hasrat, kebutuhan dan keinginan tidak dapat dipisahkan dari kehidupan manusia. Manusia selalu berusaha untuk mewujudkan hasratnya, memenuhi kebutuhan dan keinginannya. Sepanjang masa, kelas sosial, personalitas, dan gaya hidup yang berbeda selalu memberi peluang bagi dunia industri barang dan jasa. Hal yang sama terjadi dengan bisnis pasar kaget. Di Batam, untuk sembilan kecamatan yang terdiri dari karakteristik yang berbeda dari sisi variabel kelas sosial, personalitas, dan gaya hidup, berbaur di pasar kaget. Tidak ada batasan untuk segmen tertentu secara psikografis di pasar kaget Batam.

Berdasarkan simpulan diatas, maka disarankan agar diperhatikan kalau pasar kaget adalah bagian dari pasar tradisional dan tidak dapat bersaing dengan pasar modern. Orang-orang yang berjualan di pasar kaget adalah mereka dari orang yang secara segmen psikografis berada pada level bawah, maka dari itu, sekalipun lahan yang dipakai untuk pasar kaget adalah tidak sah dari pemerintah, pasar ini jangan dibinasakan melainkan dibina, untuk itu perlu peran pemerintah untuk membantu pasar ini sehingga pengelolaannya dapat lebih profesional. Pasar kaget memang menjadi saingan bagi pasar tradisional yang resmi dilahan pasar yang disediakan pemerintah, akan tetapi hal ini menjadi pertanyaan besar bagi pemerintah, bukankah pasar kaget bagaian dari pasar tradisional, tetapi mengapa para penjual dan pembeli lebih memilih transaksi di pasar kaget daripada di pasar tradisional resmi. Pemerintah perlu melakukan pembinaan baik pada pengelola pasar tradisional maupun pada unit pedagang sebagai pelaksana pasar agar tidak mengganggu pihak manapun.

\section{DAFTAR PUSTAKA}

Abdullah, Ali. (2007). Metodologi Panelitian dan Penulisan Karya Ilmiah. Cirebon: STAIN Press.

Badan Pusat Statistik Kota Batam (2015) Diperoleh tanggal 10 Januari 2017, dari

http://skpd.batamkota.go.id/batuampa r/2009/07/24/selamat-datang-diwebsite/

Keller, Lane Kevin. \& Kotler, Philip (2009). Manajemen Pemasaran, Pearson Prentice Hall, Jilid 1, Jakarta, 2009.

Keller, Lane Kevin. \& Kotler, Philip (2009). Manajemen Pemasaran, Pearson Prentice Hall, Jilid 2, Jakarta, 2009.

Peraturan Presiden Republik Indonesia Nomor: 112 Tahun 2007 Tentang Penataan dan Pembinaan Pasar Tadisional, Pusat Perbelanjaan dan Toko Modern.

Peraturan Menteri Perdagangan Repoblik Indonesia Nomor: 53/M DAG/PER/12/2008 tentang Pedoman Penataan dan Pembinaan Pasar Tradisional, Pusat Perbelanjaan dan Toko Moderen.

Purwanto, W. (2012). Analisa Persaingan Antara Pasar Tradisional Dengan Pasar Modern Studi Kasus Dikawasan Ciledug Tangerang. Jurnal MIX Vol.5 Nomor Tiga.

Smith, Jonathan A. (ed.). (2009). Psikologi kualitatif: Panduan praktis metode riset. Terjemahan dari Qualitative Psychology A Practical Guide to Research Method. Yogyakarta: Pustaka Pelajar.

Statistik Daerah Kecamatan Lubuk Baja (2015) http://batamkota.bps.go.id ii 
Statistik Daerah Kecamatan Lubuk Baja Kota Batam 2015 Statistik Daerah Kecamatan Lubuk Baja 2015 ISSN : No Publikasi : 2171.15.29 Katalog BPS : 1102001.2171.070

Syahrier, F. A. (2015). Respon Masyarakat Terhadap Keberadaan Pasar Kaget Di Kelurahan Tuah Karya Kecamatan Tampan Kota Pekanbaru. Jurnal FISIP Volume 2 Nomor satu.

Statistik Batam Kota (2015). Diperoleh tanggal 10 Januari 2017, dari https://batamkota.bps.go.id/website/p df_publikasi/Statistik-KecamatanBatu-Aji. 2015.pdf

Statistik Kecamatan Bengkong (2015) Diperoleh tanggal 10 Januari 2017, dari

http://skpd.batamkota.go.id/bengkong /2009/07/24/selamat-datang-diwebsite-kecamatan-bengkong/

Statistik Kecamatan Sagulung (2015) Diperoleh tanggal 10 Januari 2017, dari http://skpd.batamkota.go.id/kependud ukan/files/2014/09/rekapauto 201412-31_rev03.pdf

Statistik Kecamatan Batu Aji (2015) Diperoleh tanggal 10 Januari 2017, dari https://batamkota.bps.go.id/website/p df_publikasi/Statistik-KecamatanBatu-Aji-2015.pdf

Zamzani. (2013) Inisiasi Masyarakat Dan Respon Pemerintah Kota Pekanbaru (Studi Pasar Kaget Di Kecamatan Tampan 2011-2012). Diperoleh pada tanggal 20 Desember 2016, dari repository.unri.ac.id/jspui/ 